\title{
The Role of Non-cooperative Institution in Milk Marketing Chain in the District of Semarang, Central Java
}

\author{
Saptati RA \\ PhD Candidate in Agricultural Economics, College of Economics and Management \\ University of the Philippines Los Banos, College, Laguna, Philippines 4031 \\ ratnaayusaptati@yahoo.com
}

\begin{abstract}
The study aims to assess the business characteristics of milk collectors and their roles in the marketing chain of milk in the district of Semarang, Central Java. The research was based on the original data obtained by interviews using a questionnaire in January, 2015 in the sub district of Getasan. Under the random sampling method, 32 milk collectors who collect and sell milk from dairy farmers were selected. For purpose of comparison, this business was fitted into three groups, i.e., business with capacity below 100, 100-500, and above 500 liters per day. Descriptive analysis was used to explain the findings of this study. Gross margin analysis and yield (price) uncertainty ratio were also used to examine the economic benefit gained and the degree of risks faced by milk collectors. Results revealed that the covered distance, the number of milk depositors, the amount of absorbed milk, gross margin, and net income were increased with the increasing capacity of business. In line with these, the greater the business capacity, the greater the risks be borne by collectors. The coefficient of price and yield uncertainty for business with capacity of more than 500 liters/day was the highest among groups. However, for overall, both prices and yield uncertainties faced by collectors were relatively low with coefficient of less than $20 \%$. It means that risks borne by collectors were also moderately low. The roles of milk collectors in the milk marketing chain in Getasan were quite important because they were main milk suppliers for cooperatives. About $97 \%$ of milk was supplied by milk collectors. Collectors were also main milk buyers for dairy farmers. They connect farmers (either cooperative member or not) particularly in remote areas to cooperatives or greater milk collector in selling milk. They also helped farmers to overcome the problem related to limited access to formal financial institutions by providing loans.
\end{abstract}

Key Words: Non-Cooperative Institution, Role, Marketing Chain, Dairy, Semarang

\section{INTRODUCTION}

Institutional is an important part in dairy agribusiness in Indonesia because it involves many actors with various behaviors so that makes it a complex structure. Tawaf et al. (2009) stated that in dairy agribusiness, the institutional is distinguished as cooperative and non-cooperative institutions. Cooperative institution consists of farmers groups, union of farmers groups, and cooperatives. While the actors of non-cooperative institution are milk collectors and suppliers of dairy production inputs (feed, medicines and equipment). To date, most of the studies and discussions only emphasize on cooperative institutions in any aspects (Saptati \& Rusdiana 2008; Darmawan et al. 2008; Firman 2008; Munandar 2008; Sebayang 2012; Priyono \& Priyanti 2015). This is understandable because cooperatives have the greatest roles in this agribusiness, especially in distributing and marketing milk from dairy farmers up to milk processing industry.

On the other hand, study related to non-cooperative in dairy agribusiness is still rarely performed. In fact, their presence also has a significant role in this industry. One of them is milk collector, where its presence is often perceived as a threat to the survival of cooperative institutions in many regions. Considering the marketing and distributing structures, milk quality and hygiene, some argue that the presence of milk collector 
resulting a longer marketing chain, low milk price and quality of milk at farm level, thus, lowering the income of dairy farmers.

Actually, the existence of milk collector is not a new phenomenon, especially in the province of Central Java as one of the main producers of milk. Dissimilar with the provinces of West and East Java, milk collectors in Central Java have long been a fore front in milk marketing activity in this area. The shortage of milk collection center that can be provided by cooperatives, especially in remote areas, and limited number of milk processing industry in this region, opening up business opportunities for the existence of milk collector.

Seeing such facts, it is necessary to collect information associated with them. Information related to their business characteristics and their roles in dairy agribusiness needs to be examined. It is important for policy decision making in this industry in Central Java, because their existence cannot always be ruled out and be considered as a threat, since they play role in this industry. They also provide benefits, especially for farmers in remote areas to be able to sell their products.

This study aims to assess the business characteristics of milk collectors and their roles in the marketing chain of milk, particularly in the district of Semarang as the second largest milk-producing region in Central Java after Boyolali.

\section{MATERIAL AND METHODS}

Research was conducted in the district of Semarang, Central Java in January, 2015. The sub district of Getasan was selected purposively. Among all sub districts in Semarang region, Getasan has the largest population of farmers, dairy cattle, and milk production as well as milk collectors. According to the latest data, there are more than 7,000 dairy farmers who raising more than 16,000 dairy cattle (around 55.23\% of them are productive cows). A total of 32 milk collectors were selected by random sampling. Data was collected by direct interviews using questionnaires. The information gathered from milk collectors regarding household socio-demographic characteristic, business characteristics, revenue and costs of business in a year, business uncertainty, and information regarding the role of milk collector in the milk marketing chain. Descriptive analysis was used to explain the findings of the study and it was performed using the presentation of tables and graphs. In order to examine the economic benefit gained and the degree of risks faced by milk collectors, gross margin analysis and uncertainty ratio estimation was also used. The gross margin for a business is its financial output minus its variable costs. It is the estimate of returns above variable costs of a given activity. The formula of gross margin analysis is as follows (Bamiro et al. 2012):

$$
\begin{aligned}
& G M_{n}=T R_{n}-T V C_{n} \\
& T R_{n}=\sum_{i=1}^{m} P_{i} q_{i} \\
& T V C_{n}=\sum_{j=1}^{k} C_{j} X_{j} \\
& N F I_{n}=G M_{n}-T F C_{n}
\end{aligned}
$$


Where:

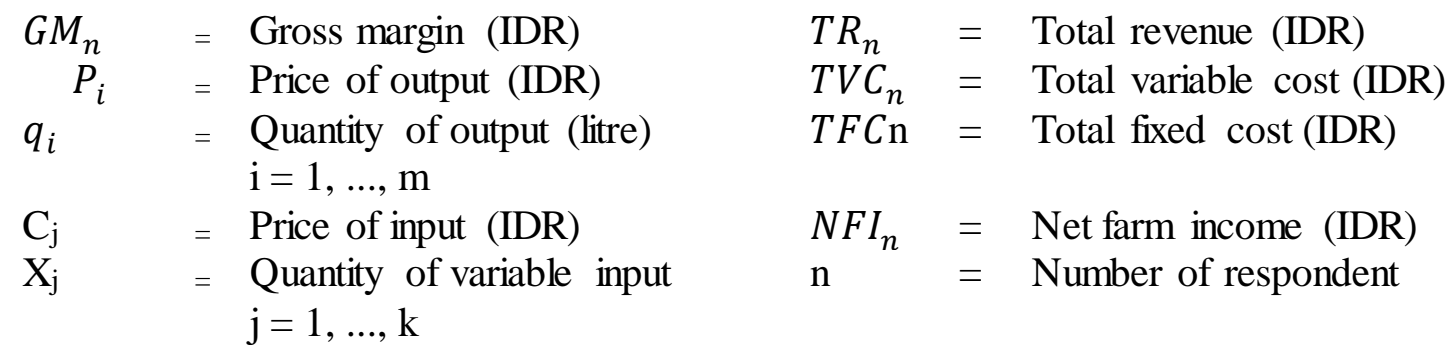

To examine the degree of risks faced by milk collectors was estimated using yield uncertainty ratio and price uncertainty ratio as proposed by Bist et al. (2006). The formula of the yield and price uncertainty ratio was as follows:

$$
\begin{aligned}
& \text { Yield uncertainty ratio }=\frac{\text { highest yield }- \text { lowest yield }}{\text { mean yield }} \\
& \text { Price uncertainty ratio }=\frac{\text { highest price }- \text { lowest price }}{\text { mean price }}
\end{aligned}
$$

The higher the coefficient, the higher would be the yield (price) uncertainty which means that collector face higher risks.

\section{RESULTS AND DISCUSSION}

\section{Respondent characteristics}

The data in the Table 1 shows the distribution of milk collectors according to gender, age, education level, main occupation, and experience as milk collector.

Table 1. The profile of respondents as milk collectors in Getasan, the district of Semarang, 2015

\begin{tabular}{lccr}
\hline \hline Characteristic & Category & Frequency & $\%$ \\
\hline Gender & Male & 30 & 93.750 \\
Age (years) & Female & 2 & 6.250 \\
& $<20$ & 1 & 3.130 \\
Education level & $21-45$ & 22 & 84.370 \\
& $46-60$ & 4 & 12.500 \\
& Elementary & 4 & 12.500 \\
Main occupation & Junior high school & 16 & 50.000 \\
& High school & 12 & 37.500 \\
& Farmer/dairy farmer & 12 & 37.500 \\
Trader/milk collector & 18 & 56.250 \\
Milk collecting & Government officer & 1 & 3.125 \\
experience & Laborer & 1 & 3.125 \\
(years) & $<5$ & 10 & 31.250 \\
\hline
\end{tabular}


Based on the results of the survey, milk collectors in this study area were dominated by male $(93.75 \%)$. It can be understood because this job requires speed and timeliness, as well as strength. The age distribution of milk collectors was dominated by a productive age range from 21-45 years (84.37\%), with the youngest collector aged 17 years while the oldest aged 51 years. The education level of respondents was moderately low, only $37.5 \%$ had a high school education and the rests had below education. Most respondents (56.25\%) made milk collection business as a main occupation with experience mostly of between 510 years.

Control over resources and assets by respondents consisting of land resources, dairy cow, family labor, hired labor, and vehicles are shown in Table 2.

Table 2. Resources and assets respondents in Getasan, the District of Semarang, 2015

\begin{tabular}{lcccc}
\hline \hline Resources & Category & Frequency & $\%$ & Average \\
\hline Land $\left(\mathrm{m}^{2}\right)$ & Dry land & 27 & 84.4 & \\
& Grass pasture & & & 1166.60 \\
Dairy cattle (heads) & - & 20 & 62.50 & 1170.30 \\
Family labor (person) & 1 & 24 & 75.00 & \\
& $2-3$ & 8 & 25.00 & \\
Hired labor (person) & & 9 & 28.13 & \\
Vehicle & Motorcycle & 15 & 46.87 & \\
& Pickup car & 17 & 53.13 & \\
\hline
\end{tabular}

It can be seen that about $84.4 \%$ of respondents had control over land resources in the forms of dry land and grass pasture. Average ownership of dry land and grass pasture were about $1166.60 \mathrm{~m}^{2}$ and $1170.30 \mathrm{~m}^{2}$ per respondent, respectively. Dry land was commonly used for farming of seasonal crops, such as various vegetables, especially corn, chilies, ginger, and tobacco. Grass pasture was used to support their dairy farming because around $62.50 \%$ of respondents were also raising dairy cattle with average of dairy cattle ownership of three heads. Respondents without dairy cattle ownership, commonly sell their grass to other dairy farmers. They can harvest their grass 4-6 times a year with range of yield of $22-30 \mathrm{~kg} / \mathrm{m}^{2} /$ year. It was also clear from Table 2 that respondents depended heavily on family labor for performing milk collection business and only $28 \%$ of them took additional labor from outside. Vehicles become an important things for their business, so all respondents had their own vehicle in the forms of motorcycle $(46.87 \%)$ and pickup car $(53.13 \%)$.

\section{Business characteristics of milk collectors}

Business characteristics of respondents regarding type of business, the number of workers, distance of area covered, the number of milk depositor and the amount of absorbed milk are shown in Table 3. For purpose of comparison, this business was fitted into three groups, i.e., for business with capacity below 100, 100- 500, and above 500 liters per day. The number of milk collectors as respondents in each group was 4, 18 and 10 persons, respectively. The data showed that all respondents (100\%) did their business individually with the maximum number of workers involved for the first, second and third group was 1, 2, and 4 persons, respectively. Collectors collected milk from farmers twice a day, i.e., in the morning and afternoon, following the pattern of milking done by farmers. 
The average number of working hours was between 3-8 hours per day, depending on the number of dairy farmers as milk depositors and the distance traveled.

Table 3. Business characteristics of milk collectors in Getasan, the district of Semarang, 2015

\begin{tabular}{lccc}
\hline \hline & \multicolumn{3}{c}{ Capacity (liters/day) } \\
\cline { 2 - 4 } Characteristics & $\begin{array}{c}<100 \\
(\mathrm{n}=4)\end{array}$ & $\begin{array}{c}100-500 \\
(\mathrm{n}=18)\end{array}$ & $\begin{array}{c}>500 \\
(\mathrm{n}=10)\end{array}$ \\
\hline Type of business & Individual & Individual & Individual \\
Number of workers (person) & 1 & $1-2$ & $1-4$ \\
Maximum covered distance by collectors (km) & 5 & 10 & 30 \\
Average number of milk depositors (person) & 10 & 33 & 77 \\
Average amount of absorbed milk (litre/day) & 60 & 310 & 1110 \\
\hline
\end{tabular}

Collectors commonly purchased milk from dairy farmers in the area around them, but some of them also purchased milk from areas that relatively farther. Most of the respondents $(87.5 \%)$ picked milk up from farmers in the remote area, while for farmers who lived in nearer area usually came to them. The farthest distance reached by collectors for the first, second and third group was 5,10 , and $30 \mathrm{~km}$, respectively. The bigger capacity of business, the farther the collector operates.

Average number of dairy farmers as milk depositor for each group was 10, 33, and 77 farmers. Approximately $84.4 \%$ of the collector considered that competition in the business was still fair, while $15.6 \%$ of them consider competition was very tight. Most of collectors did not experience difficulties finding dairy farmers who willing to supply milk or to find cooperative to sell their milk. The minimum amount of milk absorbed by collectors is 40 liters/day, and a maximum of 3000 liters/day. While, the average amount of that was 60, 310, and 1110 liters/day for each group.

\section{Economic benefit of milk collection business}

The economic benefit gained by collector from their business was calculated using gross margin analysis. Gross margin analysis on this business was also fitted into three groups as shown in Table 4.

Total revenue is the summation of the income from milk sold by milk collector. The income was derived from the difference of milk price received by the collector from cooperative with milk price paid by the collector to farmers. The price difference ranged between 100-600 IDR/liter of milk, with an average of IDR 260/liter of milk. The average total revenue for each group was IDR 5,355,000; 29,248,890 and 117,348,000, respectively ( 1 USD $=13,175$ IDR) and increase as the business size increased. The proportion of variable costs in total production costs for the first, second and third group was 89.39; 89.20; and 90.99\%, respectively. The fuel costs dominated the proportion of total variable costs, accounted for 72.95; 56.10; and $66.91 \%$ for the first, second and third group, respectively. Other costs constituting variable costs were labor cost, consumable equipment, and other costs composing of retribution and penalty from cooperative. 
Table 4. Gross margin analysis of milk collectors for a year in Getasan, the district of Semarang, 2015 (IDR)

\begin{tabular}{llrrr}
\hline \hline \multirow{2}{*}{ Component } & & \multicolumn{3}{c}{ Capacity (liters/day) } \\
\cline { 3 - 5 } & & \multicolumn{1}{c}{$\begin{array}{c}100 \\
(\mathrm{n}=4)\end{array}$} & $\begin{array}{c}100-500 \\
(\mathrm{n}=18)\end{array}$ & \multicolumn{1}{c}{$>500$} \\
& & $5,355,000$ & $29,248,890$ & $117,348,000$ \\
\hline Total revenue (TR) & Milk selling & $3,676,625$ & $15,006,945$ & $37,675,750$ \\
Total variable costs (TVC) & & $2,682,000$ & $8,418,500$ & 25.210 .800 \\
& Fuel & 900,000 & $6,300,000$ & $12,240,000$ \\
& Labor & 75,625 & 100,945 & 206,950 \\
& Consumable equipment & 19,000 & 187,500 & 18,000 \\
Gross margin (GM) & Other costs & $1,678,375$ & $14,241,945$ & $79,672,250$ \\
Total fixed cost (TFC) & (TR-TVC) & 436,250 & $1,817,167$ & $3,731,500$ \\
& & 262,500 & $1,251,667$ & $2,435,000$ \\
& Vehicle depreciation & 173,750 & 565,500 & $1,296,500$ \\
& Fixed equipment & & & \\
Net income & depreciation & $1,242,125$ & $12,424,778$ & $75,940,750$ \\
\hline
\end{tabular}

Gross margin is an important criterion that determines the competitive margin of the productive activity of business in terms of insufficient resource use. In other words, stated by Demircan et al. (2006), the success of an enterprise can be seen from its gross margin or gross profit. The average gross margin for collectors was increased with the increasing capacity of business, amounting to $1,678,375 ; 14,241,945$; and $79,672,250$ IDR for the first, second and third group, respectively. Net income for collectors increased with the increasing capacity of business, amounting to $1,242,125 ; 12,424,778$; and $75,940,750$ IDR for the first, second and third group, respectively. This net income accounted for 5, 30, and $66 \%$ of total family income for each group (Figure 1). It was found that with the increasing of business capacity there was an increase in the proportion of income from this business to the total of family income.
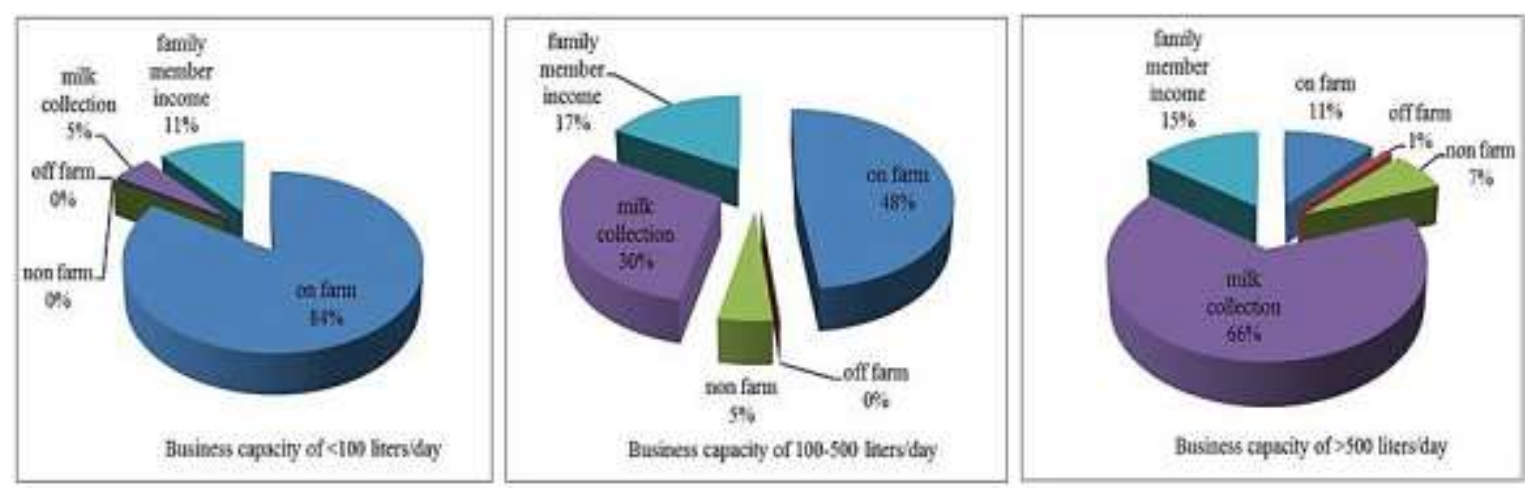

Figure 1. Proportion of income from milk collection business in the family total income

\section{Business uncertainty}

As well as dairy farming, milk collection business also faces risks in its business due to product characteristics that is perishable and need quick handling and specific treatment in the post-harvest and marketing stages. The greater the business capacity, the greater the risks be borne by collectors. Risk level can be approximated with a degree of uncertainty 
faced by the collectors, i.e., uncertainty in terms of price and yield. Figure 2 shows that both coefficient of price and yield uncertainty also increased with the increasing capacity of business.

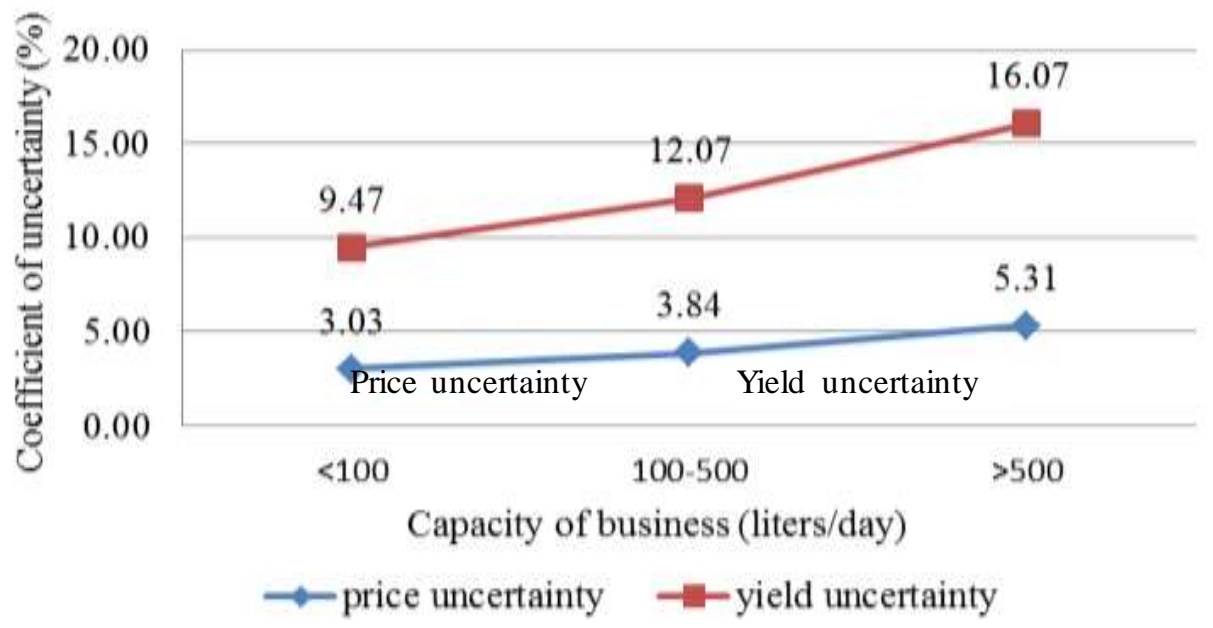

Figure 2. Yield and price uncertainty faced by milk collectors in group

Business with large capacity had to collect milk from many dairy farmers. It means that they faced more risks due to declining quality of milk since the time needed to collect milk from farmers becomes longer. Increase the number of depositors would also increase the probabilities of fraud caused by moral hazard and adverse selection problems. The moral hazard problem occurs when the collector cannot observe the effort of a farmer in dairy farming. When a farmer did not apply good management practices in raising his cows, it can lead to low production and quality of milk. While, adverse selection problem appears when collector is not well informed about a certain characteristic of a farmer, which is a good or bad farmer, which is going to cheat or not. This is because the farther the distance of collector to farmers, the collector does not know the farmers well. Thus, the collector does not know exactly what the farmer does, related to the quality of their milk. There were some farmers who still practicing mixing the milk with water result in decreasing of milk quality. The lower the quality of the milk, the lower the price of milk gained. The price uncertainty for business with capacity more than 500 liters/day had the highest coefficient of $5.13 \%$.

In line with this, larger business capacity also faced bigger uncertainty in terms of yield or milk absorbed. This was sometimes due to many farmers experienced a reduction in milk production due to the reduced number of lactating cows or there was some amount of milk that did not meet the quality standards, thus, cannot be received by the collectors. Coefficient of yield uncertainty for the first, second and third group was 9.47; 12.07; and $16.07 \%$, respectively. Overall, both price and yield uncertainties faced by collectors were relatively low with coefficient of less than $20 \%$. It means that risks borne by collectors were also moderately low because milk collectors did not produce their own milk to be sold. They only act as buyers and sellers of milk, thus they did not bear any risks in the production process like dairy farmers.

\section{The role of milk collector in the milk marketing chain}

In contrast to the provinces of East Java and West Java, milk marketing chain in Central Java cannot be separated from the role of milk collectors. Although its existence has repeatedly attempted to be eradicated with the establishment of cooperatives, but in 
fact the milk collectors are still growing rapidly. Supposedly, fresh milk collected by the cooperative should come from farmer members who deposited milk directly. However, currently, dairy cooperatives had to compete with each other in order to obtain supplies of milk. Thus, they had no longer require that only members which can become their milk depositors. There were seven cooperatives and milk collection centers in Getasan, namely KSU Andini Luhur, KSU Wahyu Agung, KUD Getasan, KTT SA Amanulloh, KTT Ngudi Sari, KTT Manunggal Karso, and Gapoktan Banyu Aji. These seven milk collection centers had a total capacity of 65 thousand liters of milk per day. Based on the study of Istianto (2012), milk collectors absorbed more than $97 \%$ of milk production of dairy farmers in the district Getasan. It means that $97 \%$ of total milk production of dairy farmers in this area was marketed through milk collectors. It shows the big contribution made by milk collectors in the marketing of milk in the district of Getasan. This condition put dairy farmers in a heavy reliance on collectors in the marketing of milk.

Milk collectors had linkages with both cooperatives (milk collecting centers) and dairy farmers. In relation to cooperatives, milk collectors act as the main suppliers of fresh milk, in addition to dairy farmers. All respondents (100\%) run their business and have had a long collaboration with cooperatives with an average time of nine years, because cooperatives as an extension of the processing industry are the main buyers of their milk. Approximately $90 \%$ of milk obtained by collectors was sold to the cooperatives and the rest was sold directly to consumers. Collectors prefer to sell their milk to cooperatives, because they can get certainty for market of milk (68.8\%), a stable price of milk (15.6\%), also can sell milk in large quantities continuously $(15,6 \%)$. A total of $68.75 \%$ of collectors was satisfied to have partnered with the cooperative due to financial supports (loans) given by cooperative to support their business. The cooperative gives loans to milk collectors to bind the relationship between the two as the certainty that the collectors will deposit their milk to cooperative. However, all respondents were still not satisfied with the milk price received and the application of strict standards of milk quality by cooperatives.

Aside from being milk suppliers to cooperatives, at the same time the collectors played role as the main buyers of dairy milk produced by farmers, especially in remote areas where there was no milk collection center or cooperative. They connected farmers (either cooperative member or not) to cooperatives or greater milk collector in selling milk. They had an informal agreement with dairy farmers who will become their milk depositors. Commonly, they operated in the area near their living area, although some big milk collectors operate in wider areas.

On the other hand, the milk collectors experienced challenges in running their business. Low production and quality of milk from dairy farmers, low price of milk set by cooperative, the problem of moral hazard and adverse selection in partnering with dairy farmers brought milk collectors in uncertainty condition. Although, the level of uncertainty faced by them was relatively low but it can lead to disturbance in the entire marketing system of milk. The main obstacle faced by many collectors was the low quality of milk produced by dairy farmers. In order to meet stringent standards of milk quality applied by cooperatives and increase the selling price of milk, the collectors encouraged farmers to improve the quality of milk production. They also tightened the acceptance of milk from farmers. If the quality of milk from farmers was very low or contain substances that were not allowed, the collectors would refuse it. However, if farmers produced milk with good quality, collectors would buy the milk at a reasonable price, i.e., the price obtained from cooperative after deducting the cost of transportation and handling of milk. The handling and transportation cost was differ for each collector, ranging from IDR 100-600 per liter milk. All collectors (100\%) made payment to dairy farmers for every 10 days in accordance with the payment schedule from cooperative. 
Collectors were also trying to improve their service to farmers. They buy equipment for milk transportation that more eligible in quality and hygiene, such as milk cans, to reduce the increasing of microbial content of milk that can affect the quality of milk. Moreover, $56.25 \%$ of collectors provide loan facility in the form of concentrate feed or cash to the farmers, because most farmers had limitations in accessing informal financial institutions due to limited collateral. These loans were not only serves as collectors' effort to help farmers cope with the difficulties in production costs, but also as a form of partnership ties between them. So, although there were other collectors who offer higher prices, farmers would normally reject. These findings were consistent with the results of Istianto (2012).

Based on these facts and seeing such strong involvement of milk collectors in milk marketing chain, it needs to think about how to make these actors to more contribute and participate in developing the dairy agribusiness. This is because ignoring them in any policy related to dairy agribusiness would not bring significant changes. Because, there is a demand and opportunity related to their presence due to limitation facilities provided by cooperatives, i.e., milk collection center that is able to reach all dairy farmers. The task of government as a facilitator should be able to provide guidance to milk collectors so that they can increasingly play their roles in enhancing production and quality of milk in the district of Semarang.

\section{CONCLUSION}

The presence of the milk collector cannot be ignored in the marketing chain of milk in the district of Semarang, particularly in the Getasan which is a sub district with the largest milk production. Milk collectors played double roles as the main buyers of milk from dairy farmers and also main suppliers of milk to the cooperatives. All respondents did their business individually with capacity of collection ranged of 40-3000 liters/day. The covered distance, the number of milk depositors, the amount of absorbed milk, gross margin, and net income were increased with the increasing capacity of business. In line with these, the greater the business capacity, the greater the risks be borne by collectors. However, for overall, both prices and yield uncertainties faced by collectors were relatively low with coefficient of less than $20 \%$.

In order to meet stringent standards of milk quality applied by cooperatives and increase the selling price of milk, the collectors encouraged farmers to improve the quality of milk production. They also tightened the acceptance of milk from farmers. The collectors encourage farmers to improve the quality of milk produced while improving their service to dairy farmers. They also helped farmers to overcome the problem related to limited access to formal financial institutions by providing loans. About $56.25 \%$ of collectors provide loan facility in the form of concentrate feed or cash to the farmers. These loans were not only serves as collectors' effort to help farmers cope with the difficulties in production costs, but also as a form of partnership ties between them.

Based on these facts and seeing such strong involvement of milk collectors in milk marketing chain, it needs to think about how to make these actors to more contribute and participate in developing the dairy agribusiness. This is because ignoring them in any policy related to dairy agribusiness would not bring significant changes. Because, there is a demand and opportunity related to their presence due to limitation facilities provided by cooperatives, i.e., milk collection center that is able to reach all dairy farmers. The task of government as a facilitator should be able to provide guidance to milk collectors so that they can increasingly play their roles in enhancing production and quality of milk in the district of Semarang. 


\section{REFERENCES}

Bamiro OM, Otunaiya AO, Idowu AO. 2012. Economic of horizontal integration in poultry industry in South-West Nigeria. Int J Poult Sci. 11:39-46.

Bist LD, Dixit AK, Sharma AK. 2006. Status of temperate fruits in Uttaranchal: Problem and prospect. In: Kishore DK, Sharma SK, Pramanick KK, editors. Temperate horticulture: Current Scenario. New Delhi (India): New India Pusblishing Agency. p. 19-26.

Darmawan, Rismayanti Y, Maryati T, Marbun O. 2008. Kelembagaan persusuan dan manfaatnya di tingkat peternak sapi perah: Studi kasus di Desa Pagerwangi, Kecamatan Lembang, Kabupaten Bandung Barat, Jawa Barat. In: Diwyanto K, Wina E, Priyanti A, Natalia L, Herawati T, Purwandaya B, editors. Prosiding Prospek Industri Sapi Perah Menuju Perdagangan Bebas 2020. Jakarta, 21 April 2008. Bogor (Indonesia): Puslitbangnak dan STEKPI. p. 534-542.

Demircan V, Binici T, Koknarogle H, Aktas AR. 2006. Economic analysis of different dairy farm sizes in Burdur Province in Turkey. Chech J Anim Sci. 51:8-17.

Firman A. 2008. Kajian koperasi persusuan di Jawa Barat. In: Firman A, Hadiana H, Hermawan, Tawaf R, Kuswaryan S, editors. Arah pengembangan industri persusuan jangka panjang, Focus Group Discussion. Bandung, 18-19 Januari 2008. Sumedang (Indonesia): Fakultas Peternakan Universitas Padjadjaran. p. 123-134.

Istianto A. 2012. Peran pengumpul, pengecer, standar mutu dan harga dalam pemasaran susu sapi di Kecamatan Getasan, Semarang, Jawa Tengah [Manuscript]. [Salatiga(Indonesia)]: Universitas Kristen Satya Wacana.

Munandar. 2008 . Restrukturisasi kelembagaan persusuan menuju partisipatif dan kesetaraan posisi tawar peternak: Kajian sosiologis kelembagaan persusuan pada usaha ternak sapi perah. In: Firman A, Hadiana H, Hermawan, Tawaf R, Kuswaryan S, editors. Arah pengembangan industri persusuan jangka panjang, Prosiding Focus Group Discussion. Sumedang (Indonesia): Fakultas Peternakan Universitas Padjadjaran. p. 144-152.

Priyono, Priyanti A. 2015. Penguatan kelembagaan koperasi susu melalui pendekatan pengembangan kawasan peternakan nasional. Wartazoa. 25:085-094.

Saptati RA, Rusdiana S. 2007. Penguatan koperasi susu untuk mendorong pengembangan usaha sapi perah rakyat. In: Diwyanto K, Wina E, Priyanti A, Natalia L, Herawati T, Purwandaya B, editors. Prosiding Prospek Industri Sapi Perah Menuju Perdagangan Bebas 2020. Jakarta, 21 April 2008. Bogor (Indonesia): Puslitbangnak dan STEKPI. p. 569-575.

Sebayang KDA. 2012. Pengembangan peternakan susu nasional melalui kelembagaan ekonomi baru. Econosains. X:211-230.

Tawaf R, Murti TW, Saptati RA. 2009. Kelembagaan dan tata niaga susu. In: Santosa KA, Diwyanto K, Toharmat T, editors. Peternakan sapi perah di Indonesia. Bogor (Indonesia): Pusat Penelitian dan Pengembangan Peternakan. p. 301-346. 